\title{
Alleviation of Heavy Metal Stress in Plants and Remediation of Soil by Rhizosphere Microorganisms
}

\author{
Jitendra Mishra, Rachna Singh and Naveen K. Arora* \\ Rhizosphere Microbiology Laboratory, Department of Environmental Microbiology, Babasaheb Bhimrao Ambedkar \\ University, Lucknow, India
}

OPEN ACCESS

Edited by:

Paula García-Fraile,

Academy of Sciences of the Czech

Republic (ASCR), Czechia

Reviewed by:

Lourdes Girard,

Universidad Nacional Autónoma de

México, Mexico

Andrzej Bajguz,

University of Białystok, Poland

${ }^{*}$ Correspondence:

Naveen K. Arora

nkarora.bbau@gmail.com

Specialty section:

This article was submitted to

Microbial Symbioses,

a section of the journal

Frontiers in Microbiology

Received: 17 July 2017

Accepted: 23 August 2017

Published: 06 September 2017

Citation:

Mishra J, Singh $R$ and Arora NK (2017) Alleviation of Heavy Metal

Stress in Plants and Remediation of Soil by Rhizosphere

Microorganisms.

Front. Microbiol. 8:1706.

doi: 10.3389/fmicb.2017.01706
Increasing concentration of heavy metals $(\mathrm{HM})$ due to various anthropogenic activities is a serious problem. Plants are very much affected by HM pollution particularly in contaminated soils. Survival of plants becomes tough and its overall health under HM stress is impaired. Remediation of HM in contaminated soil is done by physical and chemical processes which are costly, time-consuming, and non-sustainable. Metalmicrobe interaction is an emerging but under-utilized technology that can be exploited to reduce HM stress in plants. Several rhizosphere microorganisms are known to play essential role in the management of HM stresses in plants. They can accumulate, transform, or detoxify HM. In general, the benefit from these microbes can have a vast impact on plant's health. Plant-microbe associations targeting HM stress may provide another dimension to existing phytoremediation and rhizoremediation uses. In this review, applied aspects and mechanisms of action of heavy metal tolerantplant growth promoting (HMT-PGP) microbes in ensuring plant survival and growth in contaminated soils are discussed. The use of HMT-PGP microbes and their interaction with plants in remediation of contaminated soil can be the approach for the future. This low input and sustainable biotechnology can be of immense use/importance in reclaiming the HM contaminated soils, thus increasing the quality and yield of such soils.

Keywords: heavy metal, metal-microbe interaction, bioremediation, phytoremediation, contaminated soils

\section{INTRODUCTION}

Heavy metals (HM) are metals of high density. Regardless of debate on their classification, the term HM particularly in biological sense is more often used for those metals and semimetals with potential human or environmental toxicity (Tchounwou et al., 2012). Although soils are natural source of HM, geologic and anthropogenic activities increase their concentration to levels that are harmful to both plants and animals (Chibuike and Obiora, 2014). HM can be transported over long distances in gaseous as well as particulate phases (Adriano et al., 2005) which leads to their rapid accumulation in soil, water, and living systems. Although certain HM are essential for optimum plant growth but excessive amounts are harmful to the plants and other organisms in the food chain. Activities such as unpreceded use of agrochemicals and long-term application of urban sewage sludge, industrial waste disposal, waste incineration, and vehicle exhausts are the main sources of HM in agricultural soils. Soil with high concentrations of HM lead to their absorption and accumulation by plant, which ultimately pass into humans via food chain 
(Zhuang et al., 2013, 2014). Both underground and aboveground surfaces of plants can absorb HM which directly or indirectly affect plant health (Patra et al., 2004). Direct consequences are inhibition of cytoplasmic enzymes and damage to cell structures due to oxidative stress (Jadia and Fulekar, 2009). Oxidative stress is related to formation of reactive oxygen species (ROS) and cytotoxic compounds like methylglyoxal (MG) and perturbs the equilibrium of ionic homeostasis within the plant cells (Hossain et al., 2012; Sytar et al., 2013). Some HM indirectly impose oxidative stress via multiple mechanisms including glutathione depletion, binding to sulfhydryl groups of proteins (Valko et al., 2005), inhibiting antioxidative enzymes, or inducing ROSproducing enzymes like NADPH oxidases (Bielen et al., 2013). Whether direct or indirect, plants exposed to high levels of HM result in reduction or even complete cessation of all metabolic activities. Although it has been known that plants possess several defense strategies to avoid or tolerate HM intoxication but beyond certain limits these mechanisms fail and survival of plant is jeopardized (Clemens and Ma, 2016). Hence, it becomes very essential to remove the accumulated HM for normal functioning of plant and also protect organisms dependent on them. The techniques being used for HM cleanup from contaminated sites include excavation (physical removal from contaminated sites), stabilization or in situ fixation (stabilization by adding chemicals to alter metal to a state that is not absorbed by plants), and soil washing (reduction of HM by physical or chemical extraction). However, these physical processes are neither efficient nor cost effective (Schnoor, 1997). Therefore, the quest for cost effective, durable, and environmental friendly solutions to cleanup HM should be on priority. In recent past several biological means have been considered (Gavrilescu, 2004; Wuana and Okieimen, 2011). In this context phytoremediation (the use of growing plants reduces the concentration of HM in the soil) and use of rhizospheric microbes have emerged as important alternatives to ensure high efficiency and better performance. Rhizospheric microbes in particular show abilities to protect the plant from HM stress as well as help in their accumulation from soil. Microbes have metabolic capabilities supported by molecular machinery to adapt and perform even in presence of high concentration of HM. This review is focused on current understanding of rhizospheric microbes in relation to remediation of HM contamination. The review also discusses the utilization of rhizospheric microbes in fighting the HM stress in plants.

\section{HM AND RHIZOSPHERIC MICROBES}

In terrestrial ecosystems, soils are the major sink for metal contamination (Gadd, 2010). Metal concentration may range in typical soil from 1 to $100,000 \mathrm{mg} / \mathrm{kg}$ (Long et al., 2002) of which a significant part is transformed by geo-active action of soil microbes. Soil microbes especially the rhizospheric population play important role in HM detoxification in contaminated soils. This input of the rhizomicrobial population is also referred to as rhizoremediation (Kuiper et al., 2004). This involves higher metabolic activity of microbes including prokaryotes and eukaryotes near the vicinity of plants' root. According to Pires et al. (2017) the bacterial population in HM contaminated sites is predominantly composed of Firmicutes, Proteobacteria, and Actinobacteria and most represented genera belong to Bacillus, Pseudomonas, and Arthrobacter. Rhizobia are also very important plant growth promoting (PGP) microbes found in the rhizosphere. In fact nodulation and nitrogenase activities can be very sensitive to HM stress but HMT rhizobial strains have also been reported from contaminated sites effectively carrying out symbiotic nitrogen fixation. Legume-rhizobia symbiosis is widely known to detoxify $\mathrm{HM}$ and improves the quality of contaminated soils (Checcucci et al., 2017). In case of fungi, Ascomycota and Basidiomycota are the most commonly reported from HM contaminated soils (Narendrula-Kotha and Nkongolo, 2017). However, it has been also observed that nutrient poor but HM contaminated soils are often primarily colonized by arbuscular mycorrhizal (AM) fungi (Khan et al., 2000). High load of $\mathrm{HM}$ in these contaminated soils is not a problem for them. In fact, various intracellular functions of AM fungi and other rhizosphere microbes are driven by binding metal ions present in the external environment on the cell surface or to transport them into the cell (Ehrlich, 1997). In soil, they can change the metal speciation, toxicity, mobility, dissolution, and deterioration (Gadd, 2010). A large number of metals can be transformed by these microbes. Metal microbes interaction in rhizosphere is very stringent and somehow depends upon physico-chemical nature of soil, type and concentration of metal species, metabolic activity, and diversity of microbes. For further information on metal-microbes interaction one can see reviews by Khan (2005), Giller et al. (2009), Gadd (2010), and Kong and Glick (2017).

\section{MECHANISMS OF HM REMEDIATION BY HMT-PGP MICROBES}

Alleviation of HM in soil largely depends upon their availability. However, bioavailability of HM can further impair the process of phytoremediation as HM toxicity causes inefficient plant growth. HMT-PGP microbes in the rhizosphere tackle these two major problems simultaneously by modulating plant growth as well as by altering physico-chemical properties of soil to enhance metal bioavailability which trigger rapid detoxification or removal of HM from soil. Figure $\mathbf{1}$ provides schematic representation of diverse mechanisms involved in detoxification and remediation of HM in contaminated soils.

HMT-PGP microbes alter metal bioavailability in soil through acidification, chelation, complexation, precipitation, and redox reactions. Acidic $\mathrm{pH}$ conditions favor bioavailability and adsorption of HM in rhizosphere (Merdy et al., 2009). Organic acids released by HMT-PGP microbes lower soil pH and sequester soluble metal ions (Turnau and Kottke, 2005). Experimental evidences suggest that a wide array of bacteria and fungi produce organic acids as natural chelating agents of HM (Seneviratne et al., 2017). Gluconic, oxalic, acetic, and malic acids are mainly reported for HM solubilization by soil microbes (Ullah et al., 2015; Gube, 2016). In a study, Fomina et al. (2005) showed that over secretion of organic acids (oxalic 


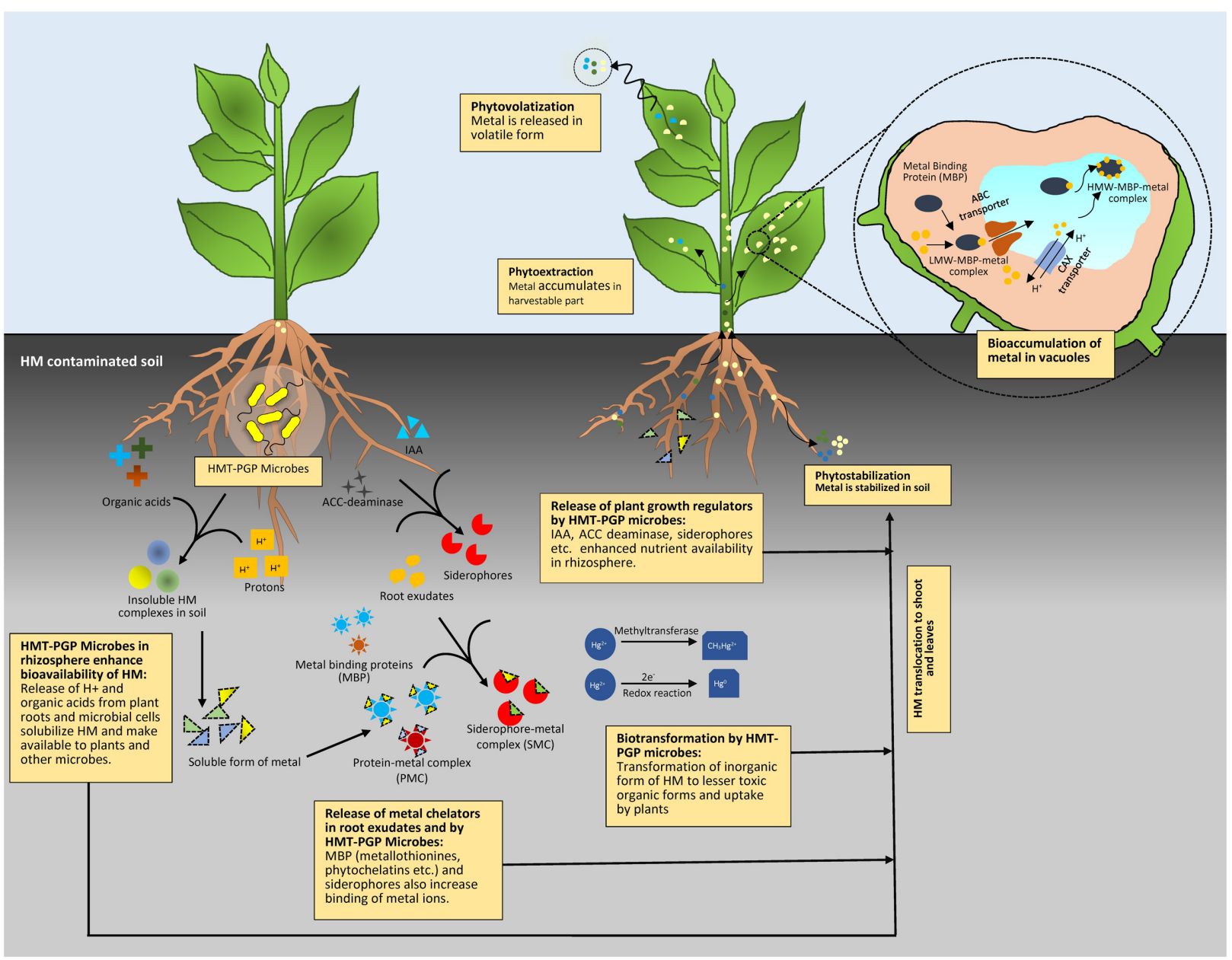

FIGURE 1 | Mechanisms involved in remediation of HM contaminated soil by HMT-PGP microbes-plant interaction.

and citric) by HM tolerant Beauveria caledonica solubilized $\mathrm{Cd}, \mathrm{Cu}, \mathrm{Pb}$, and $\mathrm{Zn}$ metals. The oxalate crystals produced by mycorrhizal fungi are also known to immobilize and detoxify HM (Gadd et al., 2014). Their filamentous hyphal structure deeply penetrates in to the deeper soil aggregates and chelates or adsorbs HM. A study by Kaewdoung et al. (2016) involving scanning electron microscopy equipped with energy dispersive $\mathrm{X}$-ray microanalysis (SEM-EDXA) and X-ray powder diffraction (XRPD) revealed that oxalate crystals produced by wood-rotting fungi Fomitopsis cf. meliae and Ganoderma aff. steyaertanum contributed in metal tolerance by transforming the metals into less toxic forms (zinc sulfate into zinc oxalate dihydrate, copper sulfate into copper oxalate hydrate, cadmium sulfate into cadmium oxalate trihydrate, and lead nitrate into lead oxalate).

Root exudates also play important role in changing metal bioavailability, as release of certain organic compounds not only mobilizes metals by forming metal complexes but also provide nutrient and energy sources to microbial communities which in turn support plant growth and survival. Root exudates contain organic acids, amino acids, and phytochelatins (PC) which perform as intracellular binding compounds for HM. Release of protons $\left(\mathrm{H}^{+}\right)$and enzymes with root exudates helps in acidification and electron transfer in the rhizosphere which leads to enhanced metal bioavailability (Ma et al., 2016). Changes in concentrations of exudate compounds in the presence of particular HM can also help in developing biomarkers. Recently, based on gas chromatography-mass spectrometry (GC-MS) and metabolomics methods, Luo et al. (2017) showed that Pbaccumulating and Sedum alfredii can significantly change the types of root exudates, and 15 compounds were identified and assumed to be potential biomarkers of $\mathrm{Pb}$ contamination.

Microbially mediated redox reactions also have profound effect on transformation of HM to less or non-toxic forms (Amstaetter et al., 2010). Outer membrane c-type cytochromes (OM c-Cyts), transouter membrane porin-cytochrome protein complex (Pcc), or MtrABC extracellular electron conduit play key role in microbial metal reduction processes (Shi et al., 2016). Such systems are well investigated in Shewanella and Geobacter species. Furthermore, HM may also be oxidized by specific enzymes. For example, multicopper oxidases such as $\mathrm{CueO}$ or $\mathrm{CuiD}$ and/or $\mathrm{CopR}$ are essentially required in $\mathrm{Cu}$ 
efflux. Whereas ChrA of chromate reductase perform reduction of $\mathrm{Cr}^{+6}$ to $\mathrm{Cr}^{+3}$. For $\mathrm{Hg}$, the protein MerA reduces $\mathrm{Hg}^{2+}$ to lesser toxic $\mathrm{Hg}^{0}$. These proteins are up-regulated under toxic HM stress. There are several instances where HMT bacteria provide substantial aid in detoxification of $\mathrm{HM}$ in plants. A study of Chatterjee et al. (2009) on Cr-tolerant bacteria Cellulosimicrobium cellulans showed transformation of toxic $\mathrm{Cr}^{6+}$ to non-toxic $\mathrm{Cr}^{3+}$ and also its enhanced uptake in the shoot and root of green chili. Majumder et al. (2013) reported biotransformation of toxic $\mathrm{As}^{3+}$ to less toxic $\mathrm{As}^{5+}$ by Asoxidizing bacteria Bacillus sp. and Geobacillus sp. isolated from As-contaminated soils.

Bioaccumulation is also largely responsible for HM uptake and further detoxification by HMT-PGP microbes. There are two combined processes which are responsible for bioaccumulation of HM. Passive uptake or "biosorption" is metabolismindependent accumulation of metals by living or inactive nonliving biomass or biological materials, whereas "active uptake" occurs only in living cells, requires metabolism and energy for the transport of metals (Gutierrez-Corona et al., 2016). Biosorption may involve one or a combination of different processes including complexation, coordination, chelation, ion exchange, microprecipitation, and entrapment (Pokethitiyook and Poolpak, 2016). Cell wall and associated functional groups like $-\mathrm{SH},-\mathrm{OH}$, and $-\mathrm{COOH}$, and other biomolecules have affinity for HM that helps in the biosorption process. Metal binding also involves chelators and metal-binding peptides, such as PC (glutathione-derived peptides) and metallothioneins (MT). PC and MT are produced by rhizospheric bacteria and fungi as well as by plants in response to HM stress and may result in the deposition of $\mathrm{HM}$ in microbial or plant cells (Miransari, 2011). MT are cysteine-rich metal peptides with high affinity for $\mathrm{Cd}, \mathrm{Cu}$, and $\mathrm{Hg}$ metals (Ahemad, 2014). In a study Murthy et al. (2011) found an increase in the MT biosynthesis in Bacillus cereus when it was exposed to increased Pb concentrations. Similarly, Sharma et al. (2017) also showed role of MT assisted periplasmic $\mathrm{Pb}$ sequestration by HMT Providencia vermicola strain SJ2A. Detoxification of HM via MT biosynthesis is also very well studied in HMT fungi. However, expression of the MT-related genes and their production in the presence $\mathrm{HM}$ has gained more attention in members of mycorrhizal fungi (Lanfranco et al., 2002; Lanfranco, 2007; Hložková et al., 2016). After entering into the cell final step of HM detoxification involves their sequestration or compartmentalization into different subcellular organelles. In mycorrhizal fungi, mainly vacuolar compartmentation of HM is noticed. Vacuolar compartmentalization of $\mathrm{Zn}, \mathrm{Cu}$, and $\mathrm{Cd}$ was observed in extraradical mycelium of Glomus intraradices renamed as Rhizophagus irregularis (González-Guerrero et al., 2008). Similarly, Yao et al. (2014) also showed vacuolar accumulation of $\mathrm{Cd}$ in $\mathrm{Cd}$-exposed extraradical mycelium of $R$. irregularis in symbiosis with clover.

Microbial communities in the rhizosphere also excrete extracellular polymeric substances (EPS) such as polysaccharides, glycoprotein, lipopolysaccharide, and soluble peptide which possess substantial quantity of anion functional groups and help to remove or recover metals from the rhizosphere through biosorption (Ayangbenro and Babalola, 2017). EPS production by certain PGP microbes induce biofilm formation in response to the exposure of toxic HM. Biofilm formation enhances tolerance of microbial cells by forming a protective sheath as well as transform toxic metal ions into non-toxic forms after adsorption. EPS produced by rhizobia and other PGP microbes with multiple number of anionic groups are reported to sequester several types of HM (Gupta and Diwan, 2017).

\section{PLANT GROWTH PROMOTION AND HM REMOVAL FROM SOIL BY HMT-PGP MICROBES}

HMT-PGP microbes not only contribute in growth enhancement of host plant but also accelerate the removal of HM from contaminated soils. This may occur due to enhanced or balanced plant growth under HM stress or by increasing the bioavailability of metals for easy uptake by plants and microbial cells. In rhizospheric microbial communities, PGP traits such as release of extracellular enzymes, siderophores, phytohormones, solubilization of insoluble form of minerals (phosphate, $\mathrm{Zn}$, and $\mathrm{K}$ ), and fixation of nitrogen provide plant growth promotion and simultaneously reduce adverse effect of $\mathrm{HM}$ on plants health.

Abiotic stresses (including HM) induce the production of stress hormone ethylene in plants, leading to suppressed plant growth and reduced root proliferation. Enhanced plant growth under HM contamination by enzyme 1-aminocyclopropane-1carboxylate (ACC) deaminase producing microorganisms has been widely reported (Zhang et al., 2011; Han et al., 2015). High concentration of ethylene adversely affects root growth and proliferation in HM contaminated soils, ACC deaminase regulates its concentration by metabolizing ethylene precursor ACC and helps in plant survival under stress conditions. Phytohormone, indole acetic acid (IAA) produced by HMT-PGP microorganisms also induce root elongation and development of lateral and adventitious roots to overcome HM toxicity and hence improve plant growth. IAA producing strain B. subtilis SJ101 stimulated the growth of Brassica juncea in Ni-contaminated soil (Zaidi et al., 2006). Similarly, $\mathrm{Zn}, \mathrm{Cu}, \mathrm{Ni}$, and $\mathrm{Co}$ tolerant IAA producing strains were found to induce rapid root elongation in B. juncea in Cd contaminated soil (Belimov et al., 2005). Besides IAA and ACC deaminase, phosphate solubilizers, siderophore producers, and nitrogen fixing HMT-PGP microbes also assist in plant growth and root development by enhanced nutrient availability as well as by changing bioavailability of HM (Wu et al., 2010; Gupta et al., 2014). Pinter et al. (2017) found that siderophore production, phosphate solubilization, and nitrogen fixation activities of As tolerant B. licheniformis, Micrococcus luteus, and Pseudomonas fluorescens increased the biomass of grapevine in the presence of high As concentration. Environmental adaptability of $\mathrm{Cd}, \mathrm{Pb}$, and $\mathrm{Cu}$ resistant bacteria from rhizospheric soil of Boehmeria nivea growing around mine refineries was evaluated by Jiang et al. (2017) and they showed rhizosphere bacteria belonging to genera Pseudomonas, Cupriavidus, Bacillus, and Acinetobacter showed tolerance to $\mathrm{Cd}$, 
$\mathrm{Pb}$, and $\mathrm{Cu}$ at high concentrations. A wide array of PGP traits of rhizobia including fixation of nitrogen, solubilization of insoluble minerals such as phosphate, phytohormones production, release of siderophores, production of ACC deaminase, and volatile compounds such as acetoin and 2, 3-butanediol make rhizobia very good candidates for detoxification of HM and carry out rhizo and phytoremediation along with their partner legumes (Hao et al., 2014; Rangel et al., 2017). Rhizobia because of their symbiotic nitrogen fixation ability are well known to enhance the yield of legumes in HM contaminated soils (Arora et al., 2010). AM fungi are also reported to enhance the growth of plants in HM contaminated soils. Ruscitti et al. (2017) tested effect of inoculation of AM fungi on pepper growth in response to increasing soil $\mathrm{Cu}$ concentrations and found total dry weight and the leaf area was higher in mycorrhizal plants.

In spite of great potential, HMT-PGP microbes and their relations with host plants under HM contaminated soils are very less understood and required to be explored further. Further research using latest biotechnological tools and field studies should be done to determine synergistic action of HMT-PGP microbes in enhancing the growth of plant and their mechanisms of mobilization, transformation, and detoxification of HM in contaminated soils.

\section{APPLICATIONS AND FUTURE CHALLENGES}

Use of HMT-PGP microbes along with their host plants for remediation of HM contaminated soils can be an ecofriendly and economic approach. However, there is still lack of knowledge to implement this technology at commercialization level. Accumulation of HM in plant tissues often downturns the remediation process when the contaminated sites are heavily polluted (Ma et al., 2011). In some instances where soil is contaminated with multiple types of $\mathrm{HM}$, use of HMT-PGP microbes with additives (nutrients) is found to be more useful. Recently in microcosm-scale phytoextraction experiments, Franchi et al. (2017) showed that addition of thiosulfate with HMT-PGP microbes enhanced mobilization and uptake of $\mathrm{As}$ and $\mathrm{Hg}$ in B. juncea and L. albus grown in soil polluted with both metals. For phytoextraction of HM, use of non-food crops such as those used in timber or other commercial purposes (not involving human or animal consumption) can be targeted. This will result in removal of HM from the soil and non-transfer to the food chain. Use of genetically engineered microbes (GEM) well adapted to local conditions (soil and climatic) can also be done for efficient removal of HM from contaminated soils (Das et al., 2016; Gupta and Singh, 2017). Biostimulation of local microbial population by adding nutrients can also be an approach to encourage remediation and detoxification of HM contaminated soils (Fulekar et al., 2012). HMT microbes in consortium have recently been evaluated for their effectiveness in remediating HM from contaminated sites. A recent study by Migahed et al. (2017) showed that mixture of HMT bacterial biomass and fungal spores successfully removed $\mathrm{Cr}$ and $\mathrm{Fe}$ ions from industrial effluents. Entomopathogenic fungi can also be used in HM removal from contaminated soils (Gola et al., 2016). This can serve the purpose of biocontrol and remediation simultaneously in infested and polluted soils.

Pathway-engineering techniques to design or modify microbes and plants for enhanced HM removal can be useful (Mosa et al., 2016). Overexpression of metal-binding proteins, chelators, metal transforming, and detoxifying enzymes are the key traits being used in transgenic plants and GEM for remediating HM. Use of genetic engineering to construct "microbial biosensors" with enhanced potential of rapid detection of contaminated sites and accurate measurement of degree of contamination is also a promising technology (Dixit et al., 2015). Although GEM undoubtedly have greater remediation potential but studies related to their impact on eco-systems and regulation hurdles (related to biosecurity, diversity, end-users, government clearance) need to be overcome before the commercial use. Recent research shows that studies of plant microbiome from contaminated soils may boost existing phytoremediation technology for remediation of HM (Thijs et al., 2017).

\section{CONCLUSION}

Contamination of agricultural soils with HM is becoming a serious environmental issue and finding economical and eco-friendly techniques to tackle this problem is on priority. Application of plant-microbe synergy to restore lands, contaminated with pollutants is a promising technique that is still in benign stage. Benefits of HMT-PGP microorganisms are immense as they perform multiple functions such as improved soil quality, enhanced plant growth, detoxification, and removal of HM from soil. However, further research is required to develop suitable bioformulations using HMT-PGP microbes for remediation and utilization of contaminated soils.

\section{AUTHOR CONTRIBUTIONS}

NA and JM conceived the idea; NA, RS, and JM prepared the manuscript; JM prepared illustration; and NA supervised the whole study.

\section{ACKNOWLEDGMENT}

The authors would like to thank Prof. R. C. Sobti, Vice Chancellor, BBA University for his support and for providing academic flexibility during the entire course of work. 


\section{REFERENCES}

Adriano, D. C., Bolan, N. S., Vangronsveld, J., and Wenzel, W. W. (2005). "Heavy metals," in Encyclopedia of Soils in the Environment, ed. D. Hillel (Amsterdam: Elsevier), 175-182. doi: 10.1016/B0-12-348530-4/00196-X

Ahemad, M. (2014). Remediation of metalliferous soils through the heavy metal resistant plant growth promoting bacteria: paradigms and prospects. Arab. J. Chem. doi: 10.1016/j.arabjc.2014.11.020 [Epub ahead of print].

Amstaetter, K., Borch, T., Larese-Casanova, P., and Kappler, A. (2010). Redox transformation of arsenic by $\mathrm{Fe}$ (II)-activated goethite $(\alpha-\mathrm{FeOOH})$. Environ. Sci. Technol. 44, 102-108. doi: 10.1021/es901274s

Arora, N. K., Khare, E., Singh, S., and Maheshwari, D. K. (2010). Effect of Al and heavy metals on enzymes of nitrogen metabolism of fast and slow growing rhizobia under explanta conditions. World J. Microbiol. Biotechnol. 26, 811-816. doi: 10.1007/s11274-009-0237-6

Ayangbenro, A., and Babalola, O. (2017). A new strategy for heavy metal polluted environments: a review of microbial biosorbents. Int. J. Environ. Res. Public Health 14:94. doi: 10.3390/ijerph14010094

Belimov, A. A., Hontzeas, N., Safronova, V. I., Demchinskaya, S. V., Piluzza, G., Bullitta, S., et al. (2005). Cadmium-tolerant plant growth promoting rhizobacteria associated with the roots of Indian mustard (Brassica juncea L. Czern.). Soil Biol. Biochem. 37, 241-250. doi: 10.1016/j.soilbio.2004.07.033

Bielen, A., Remans, T., Vangronsveld, J., and Cuypers, A. (2013). The influence of metal stress on the availability and redox state of ascorbate, and possible interference with its cellular functions. Int. J. Mol. Sci. 14, 6382-6413. doi: 10.3390/ijms14036382

Chatterjee, S., Sau, G. B., and Mukherjee, S. K. (2009). Plant growth promotion by a hexavalent chromium reducing bacterial strain, Cellulosimicrobium cellulans KUCr3. World J. Microbiol. Biotechnol. 25, 1829-1836. doi: 10.1007/s11274009-0084-5

Checcucci, A., Bazzicalupo, M., and Mengoni, A. (2017). "Exploiting nitrogenfixing rhizobial symbionts genetic resources for improving phytoremediation of contaminated soils," in Enhancing Cleanup of Environmental Pollutants: Biological Approaches, Vol. 1, eds A. Naser, A. Anjum, S. S. Gill, and N. Tuteja (Cham: Springer International Publishing), 275-288. doi: 10.1007/978-3-31955426-6_13

Chibuike, G. U., and Obiora, S. C. (2014). Heavy metal polluted soils: effect on plants and bioremediation methods. Appl. Environ. Soil Sci. 2014:752708. doi: $10.1155 / 2014 / 752708$

Clemens, S., and Ma, J. F. (2016). Toxic heavy metal and metalloid accumulation in crop plants and foods. Annu. Rev. Plant Biol. 67, 489-512. doi: 10.1146/ annurev-arplant-043015-112301

Das, S., Dash, H. R., and Chakraborty, J. (2016). Genetic basis and importance of metal resistant genes in bacteria for bioremediation of contaminated environments with toxic metal pollutants. Appl. Microbiol. Biotechnol. 100, 2967-2984. doi: 10.1007/s00253-016-7364-4

Dixit, R., Wasiullah, Malaviya, D., Pandiyan, K., Singh, U. B., Sahu, A., et al. (2015). Bioremediation of heavy metals from soil and aquatic environment: an overview of principles and criteria of fundamental processes. Sustainability 7:2189. doi: 10.3390/su7022189

Ehrlich, H. L. (1997). Microbes and metals. Appl. Microbiol. Biotechnol. 48, 687-692. doi: 10.1007/s002530051116

Fomina, M., Hillier, S., Charnock, J. M., Melville, K., Alexander, I. J., and Gadd, G. M. (2005). Role of oxalic acid overexcretion in transformations of toxic metal minerals by Beauveria caledonica. Appl. Environ. Microbiol. 71, 371-381. doi: 10.1128/aem.71.1.371-381.2005

Franchi, E., Rolli, E., Marasco, R., Agazzi, G., Borin, S., Cosmina, P., et al. (2017). Phytoremediation of a multi contaminated soil: mercury and arsenic phytoextraction assisted by mobilizing agent and plant growth promoting bacteria. J. Soils Sediments 17, 1224-1236. doi: 10.1007/s11368-015-1346-5

Fulekar, M. H., Sharma, J., and Tendulkar, A. (2012). Bioremediation of heavy metals using biostimulation in laboratory bioreactor. Environ. Monit. Assess. 184, 7299-7307. doi: 10.1007/s10661-011-2499-3

Gadd, G. M. (2010). Metals, minerals and microbes: geomicrobiology and bioremediation. Microbiology 156(Pt 3), 609-643. doi: 10.1099/mic.0.037143-0

Gadd, G. M., Bahri-Esfahani, J., Li, Q., Rhee, Y. J., Wei, Z., Fomina, M., et al. (2014). Oxalate production by fungi: significance in geomycology, biodeterioration and bioremediation. Fungal Biol. Rev. 28, 36-55. doi: 10.1016/j.fbr.2014.05.001
Gavrilescu, M. (2004). Removal of heavy metals from the environment by biosorption. Eng. Life Sci. 4, 219-232. doi: 10.1002/elsc.200420026

Giller, K. E., Witter, E., and McGrath, S. P. (2009). Heavy metals and soil microbes. Soil Biol. Biochem. 41, 2031-2037. doi: 10.1016/j.soilbio.2009.04.026

Gola, D., Dey, P., Bhattacharya, A., Mishra, A., Malik, A., Namburath, M., et al. (2016). Multiple heavy metal removal using an entomopathogenic fungi Beauveria bassiana. Bioresour. Technol. 218, 388-396. doi: 10.1016/j.biortech. 2016.06.096

González-Guerrero, M., Melville, L. H., Ferrol, N., Lott, J. N., Azcon-Aguilar, C., and Peterson, R. L. (2008). Ultrastructural localization of heavy metals in the extraradical mycelium and spores of the arbuscular mycorrhizal fungus Glomus intraradices. Can. J. Microbiol. 54, 103-110. doi: 10.1139/w07-119

Gube, M. (2016). "Fungal molecular response to heavy metal stress," in Biochemistry and Molecular Biology, ed. D. Hoffmeister (Cham: Springer International Publishing), 47-68.

Gupta, D. K., Chatterjee, S., Datta, S., Veer, V., and Walther, C. (2014). Role of phosphate fertilizers in heavy metal uptake and detoxification of toxic metals. Chemosphere 108, 134-144. doi: 10.1016/j.chemosphere.2014.01.030

Gupta, P., and Diwan, B. (2017). Bacterial exopolysaccharide mediated heavy metal removal: a review on biosynthesis, mechanism and remediation strategies. Biotechnol. Rep. 13, 58-71. doi: 10.1016/j.btre.2016.12.006

Gupta, S., and Singh, D. (2017). "Role of genetically modified microorganisms in heavy metal bioremediation," in Advances in Environmental Biotechnology, eds R. Kumar, A. K. Sharma, and S. S. Ahluwalia (Singapore: Springer), 197-214.

Gutierrez-Corona, J. F., Romo-Rodriguez, P., Santos-Escobar, F., Espino-Saldana, A. E., and Hernandez-Escoto, H. (2016). Microbial interactions with chromium: basic biological processes and applications in environmental biotechnology. World J. Microbiol. Biotechnol. 32, 191. doi: 10.1007/s11274-016-2150-0

Han, Y., Wang, R., Yang, Z., Zhan, Y., Ma, Y., Ping, S., et al. (2015) 1-aminocyclopropane-1-carboxylate deaminase from Pseudomonas stutzeri a1501 facilitates the growth of rice in the presence of salt or heavy metals. J. Microbiol. Biotechnol. 25, 1119-1128. doi: 10.4014/jmb.1412.12053

Hao, X., Taghavi, S., Xie, P., Orbach, M. J., Alwathnani, H. A., Rensing, C., et al. (2014). Phytoremediation of heavy and transition metals aided by legume-rhizobia symbiosis. Int. J. Phytoremediation 16, 179-202. doi: 10.1080/ 15226514.2013 .773273

Hložková, K., Matěnová, M., Žáčková, P., Strnad, H., Hršelová, H., Hroudová, M., et al. (2016). Characterization of three distinct metallothionein genes of the Ag-hyperaccumulating ectomycorrhizal fungus Amanita strobiliformis. Fungal Biol. 120, 358-369. doi: 10.1016/j.funbio.2015.11.007

Hossain, M. A., Piyatida, P., da Silva, J. A. T., and Fujita, M. (2012). Molecular mechanism of heavy metal toxicity and tolerance in plants: central role of glutathione in detoxification of reactive oxygen species and methylglyoxal and in heavy metal chelation. J. Bot. 2012:872875. doi: 10.1155/2012/872875

Jadia, C. D., and Fulekar, M. H. (2009). Phytoremediation of heavy metals: recent techniques. Afr. J. Biotechnol. 8, 921-928.

Jiang, J., Pan, C., Xiao, A., Yang, X., and Zhang, G. (2017). Isolation, identification, and environmental adaptability of heavy-metal-resistant bacteria from ramie rhizosphere soil around mine refinery. 3 Biotech 7, 5. doi: 10.1007/s13205-0170603-2

Kaewdoung, B., Sutjaritvorakul, T., Gadd, G. M., Whalley, A. J. S., and Sihanonth, P. (2016). Heavy metal tolerance and biotransformation of toxic metal compounds by new isolates of wood-rotting fungi from Thailand. Geomicrobiol. J. 33, 283-288. doi: 10.1080/01490451.2015.1048394

Khan, A. G. (2005). Role of soil microbes in the rhizospheres of plants growing on trace metal contaminated soils in phytoremediation. J. Trace Elements Med. Biol. 18, 355-364. doi: 10.1016/j.jtemb.2005.02.006

Khan, A. G., Kuek, C., Chaudhry, T. M., Khoo, C. S., and Hayes, W. J. (2000). Role of plants, mycorrhizae and phytochelators in heavy metal contaminated land remediation. Chemosphere 41, 197-207. doi: 10.1016/S0045-6535(99)00412-9

Kong, Z., and Glick, B. R. (2017). The role of plant growth-promoting bacteria in metal phytoremediation. Adv. Microbial Physiol. 71, 97-132. doi: 10.1016/bs ampbs.2017.04.001

Kuiper, I., Lagendijk, E. L., Bloemberg, G. V., and Lugtenberg, B. J. J. (2004). Rhizoremediation: a beneficial plant-microbe interaction. Mol. Plant Microbe Interact. 17, 6-15. doi: 10.1094/MPMI.2004.17.1.6

Lanfranco, L. (2007). The fine-tuning of heavy metals in mycorrhizal fungi. New Phytol. 174, 3-6. doi: 10.1111/j.1469-8137.2007.02029.x 
Lanfranco, L., Bolchi, A., Ros, E. C., Ottonello, S., and Bonfante, P. (2002). Differential expression of a metallothionein gene during the presymbiotic versus the symbiotic phase of an arbuscular mycorrhizal fungus. Plant Physiol. 130, 58-67. doi: 10.1104/pp.003525

Long, X. X., Yang, X. E., and Ni, W. Z. (2002). Current status, and prospective on phytoremediation of heavy metal polluted soils. J. Appl. Ecol. 13, 757-762. doi: $10.1631 /$ jzus.B0710633

Luo, Q., Wang, S., Sun, L.-N., and Wang, H. (2017). Metabolic profiling of root exudates from two ecotypes of Sedum alfredii treated with $\mathrm{Pb}$ based on GC-MS. Sci. Rep. 7:39878. doi: 10.1038/srep39878

Ma, Y., Oliveira, R. S., Freitas, H., and Zhang, C. (2016). Biochemical and molecular mechanisms of plant-microbe-metal interactions: relevance for phytoremediation. Front. Plant Sci. 7:918. doi: 10.3389/fpls.2016.00918

Ma, Y., Prasad, M. N. V., Rajkumar, M., and Freitas, H. (2011). Plant growth promoting rhizobacteria and endophytes accelerate phytoremediation of metalliferous soils. Biotechnol. Adv. 29, 248-258. doi: 10.1016/j.biotechadv. 2010.12.001

Majumder, A., Bhattacharyya, K., Bhattacharyya, S., and Kole, S. C. (2013). Arsenictolerant, arsenite-oxidising bacterial strains in the contaminated soils of West Bengal. India. Sci. Total Environ. 46, 1006-1014. doi: 10.1016/j.scitotenv.2013. 06.068

Merdy, P., Gharbi, L. T., and Lucas, Y. (2009). Pb, Cu and Cr interactions with soil: sorption experiments and modelling. Colloids Surf. A 347, 192-199. doi: 10.1016/j.colsurfa.2009.04.004

Migahed, F., Abdelrazak, A., and Fawzy, G. (2017). Batch and continuous removal of heavy metals from industrial effluents using microbial consortia. Int. J. Environ. Sci. Technol. 14, 1169-1180. doi: 10.1007/s13762-016-1229-3

Miransari, M. (2011). Hyperaccumulators, arbuscular mycorrhizal fungi and stress of heavy metals. Biotechnol. Adv. 29, 645-653. doi: 10.1016/j.biotechadv.2011. 04.006

Mosa, K. A., Saadoun, I., Kumar, K., Helmy, M., and Dhankher, O. P. (2016). Potential biotechnological strategies for the cleanup of heavy metals and metalloids. Front. Plant Sci. 7:303. doi: 10.3389/fpls.2016.00303

Murthy, S., Bali, G., and Sarangi, S. (2011). Effect of lead on metallothionein concentration in leadresistant bacteria Bacillus cereus isolated from industrial effluent. Afr. J. Biotechnol. 10, 15966-15972. doi: 10.5897/AJB11.1645

Narendrula-Kotha, R., and Nkongolo, K. K. (2017). Microbial response to soil liming of damaged ecosystems revealed by pyrosequencing and phospholipid fatty acid analyses. PLOS ONE 12:e0168497. doi: 10.1371/journal.pone.0168497

Patra, M., Bhowmik, N., Bandopadhyay, B., and Sharma, A. (2004). Comparison of mercury, lead and arsenic with respect to genotoxic effects on plant systems and the development of genetic tolerance. Environ. Exp. Bot. 52, 199-223. doi: 10.1016/j.envexpbot.2004.02.009

Pinter, I. F., Salomon, M. V., Berli, F., Bottini, R., and Piccoli, P. (2017). Characterization of the As (III) tolerance conferred by plant growth promoting rhizobacteria to in vitro-grown grapevine. Appl. Soil Ecol. 109, 60-68. doi: 10.1016/j.apsoil.2016.10.003

Pires, C., Franco, A. R., Pereira, S. I. A., Henriques, I., Correia, A., Magan, N., et al. (2017). Metal(loid)-contaminated soils as a source of culturable heterotrophic aerobic bacteria for remediation applications. Geomicrobiol. J. 1-9. doi: 10.1080/01490451.2016.1261968

Pokethitiyook, P., and Poolpak, T. (2016). "Biosorption of heavy metal from aqueous solutions," in Phytoremediation: Management of Environmental Contaminants, Vol. 3, eds A. A. Ansari, S. S. Gill, R. Gill, G. R. Lanza, and L. Newman (Cham: Springer International Publishing), 113-114.

Rangel, W. M., Thijs, S., Janssen, J., Oliveira Longatti, S. M., Bonaldi, D. S., Ribeiro, P. R., et al. (2017). Native rhizobia from $\mathrm{Zn}$ mining soil promote the growth of Leucaena leucocephala on contaminated soil. Int. J. Phytoremediation 19, 142-156. doi: 10.1080/15226514.2016.1207600

Ruscitti, M., Arango, M., and Beltrano, J. (2017). Improvement of copper stress tolerance in pepper plants (Capsicum annuum L.) by inoculation with arbuscular mycorrhizal fungi. Theor. Exp. Plant Physiol. 29, 37-49. doi: 10.1007/ s40626-016-0081-7

Schnoor, J. (1997). Phytoremediation. Technology Evaluation Report TE-98-01. Pittsburgh, PA: Groundwater Remediation Technologies Analysis Center.

Seneviratne, M., Seneviratne, G., Madawala, H., and Vithanage, M. (2017). "Role of rhizospheric microbes in heavy metal uptake by plants," in Agro-Environmental
Sustainability: Managing Environmental Pollution, Vol. 2, eds J. S. Singh and G. Seneviratne (Cham: Springer International Publishing), 147-163.

Sharma, J., Shamim, K., Dubey, S. K., and Meena, R. M. (2017). Metallothionein assisted periplasmic lead sequestration as lead sulfite by Providencia vermicola strain SJ2A. Sci. Total Environ. 579, 359-365. doi: 10.1016/j.scitotenv.2016. 11.089

Shi, L., Dong, H., Reguera, G., Beyenal, H., Lu, A., Liu, J., et al. (2016). Extracellular electron transfer mechanisms between microorganisms and minerals. Nat. Rev. Microbiol. 14, 651-662. doi: 10.1038/nrmicro.2016.93

Sytar, O., Kumar, A., Latowski, D., Kuczynska, P., Strzałka, K., and Prasad, M. N. V. (2013). Heavy metal-induced oxidative damage, defense reactions, and detoxification mechanisms in plants. Acta Physiol. Plant. 35, 985-999. doi: 10.1007/s11738-012-1169-6

Tchounwou, P. B., Yedjou, C. G., Patlolla, A. K., and Sutton, D. J. (2012). Heavy metals toxicity and the environment. EXS 101, 133-164. doi: 10.1007/978-37643-8340-4_6

Thijs, S., Sillen, W., Weyens, N., and Vangronsveld, J. (2017). Phytoremediation: state-of-the-art and a key role for the plant microbiome in future trends and research prospects. Int. J. Phytoremediation 19, 23-38. doi: 10.1080/15226514. 2016.1216076

Turnau, K., and Kottke, I. (2005). "Fungal activity as determined by microscale methods with special emphasis on interactions with heavy metals," in The Fungal Community, eds J. Dighton and J. F. White (Boca Raton: CRC Press), 287-305.

Ullah, A., Heng, S., Munis, M. F. H., Fahad, S., and Yang, X. (2015). Phytoremediation of heavy metals assisted by plant growth promoting (PGP) bacteria: a review. Environ. Exp. Bot. 117, 28-40. doi: 10.1016/j.envexpbot.2015. 05.001

Valko, M., Morris, H., and Cronin, M. T. D. (2005). Metals, toxicity and oxidative stress. Curr. Med. Chem. 12, 1161-1208. doi: 10.2174/0929867053764635

Wu, G., Kang, H., Zhang, X., Shao, H., Chu, L., and Ruan, C. (2010). A critical review on the bio-removal of hazardous heavy metals from contaminated soils: issues, progress, eco-environmental concerns and opportunities. J. Hazard. Mater. 174, 1-8. doi: 10.1016/j.jhazmat.2009.09.113

Wuana, R. A., and Okieimen, F. E. (2011). Heavy metals in contaminated soils: a review of sources, chemistry, risks and best available strategies for remediation. ISRN Ecol. 2011:402647. doi: 10.5402/2011/402647

Yao, Q., Yang, R., Long, L., and Zhu, H. (2014). Phosphate application enhances the resistance of arbuscular mycorrhizae in clover plants to cadmium via polyphosphate accumulation in fungal hyphae. Environ. Exp. Bot. 108, 63-70. doi: 10.1016/j.envexpbot.2013.11.007

Zaidi, S., Usmani, S., Singh, B. R., and Musarrat, J. (2006). Significance of Bacillus subtilis strain SJ 101 as a bioinoculant for concurrent plant growth promotion and nickel accumulation in Brassica juncea. Chemosphere 64, 991-997. doi: 10.1016/j.chemosphere.2005.12.057

Zhang, X., Xia, H., Li, Z., Zhuang, P., and Gao, B. (2011). Identification of a new potential Cd-hyperaccumulator Solanum photeinocarpum by soil seed bank-metal concentration gradient method. J. Hazard. Mater. 189, 414-419. doi: 10.1016/j.jhazmat.2011.02.053

Zhuang, P., Li, Z. A., McBride, M. B., and Zou, B. (2013). Health risk assessment for consumption of fish originating from ponds near Dabaoshan mine, South China. Environ. Sci. Pollut. Res. 20, 5844-5854. doi: 10.1007/s11356-0131606-0

Zhuang, P., Lu, H., Li, Z., Zou, B., and McBride, M. B. (2014). Multiple exposure and effects assessment of heavy metals in the population near mining area in South China. PLoS ONE 9:e94484. doi: 10.1371/journal.pone.0094484

Conflict of Interest Statement: The authors declare that the research was conducted in the absence of any commercial or financial relationships that could be construed as a potential conflict of interest.

Copyright $\odot 2017$ Mishra, Singh and Arora. This is an open-access article distributed under the terms of the Creative Commons Attribution License (CC BY). The use, distribution or reproduction in other forums is permitted, provided the original author(s) or licensor are credited and that the original publication in this journal is cited, in accordance with accepted academic practice. No use, distribution or reproduction is permitted which does not comply with these terms. 